\title{
Service Science And Accounting
}

\author{
Stephen G. Kerr, Bradley University, USA
}

\begin{abstract}
The evolution of a new discipline of service science will creatively disturb the relationship between more established business disciplines. Each discipline is not an independent silo. As a result the purpose of this paper was to explore, at this early stage, how the new discipline may create opportunities for interdisciplinary scholarship. The specific purpose of this paper was to explore how service science might interact with the scholarly and professional practice of accounting. Accounting practice is dominated by a stewardship proposition. The stewardship proposition is a problem because typical service science investments will receive unfavorable treatment. Accounting's other major proposition is valuation. Areas of opportunity for positive contributions from a service science approach are discussed. Service science, as viewed through an accounting lens, will have to find ways to overcome measurement and reporting methods that will not afford service science investments the full benefit of their strategic potential. Several avenues for research into ways service science can improve accounting scholarship are suggested.
\end{abstract}

Keywords: Service Science, Accounting, Service, Performance evaluation, Capital Budgeting, Valuation, Responsibility Accounting, Cross Disciplinary Research, Capital Budgeting.

\section{INTRODUCTION}

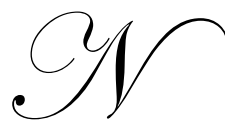

obody can determine the exact moment when a concept gains sufficient recognition to be called a professional discipline. Once a concept is introduced it will gain a following to the extent that its basic idea provides new insight into the world around us. As visionaries share their concept it will come under greater scrutiny. If that audience grows we will eventually have a new discipline. One need only look back on the relatively recent progression of supply chain management to illustrate this point. Clearly the formation of specialized journals and broader application of the concept is part of the journey. This paper explores how the emerging discipline of service science will relate to the scholarly and professional practice of accounting.

When is it safe to declare we have a new discipline? The process can never be conclusive. There are legal scholars that still think that Harvard University made a mistake when it created the Business School as an alternative route into industry for young men! It is also possible to find economists that do not find accounting to be a legitimate field of scholarship. Recognition will be slow and based on the production of lasting and genuinely new concepts. If service science can address issues that are not adequately answered elsewhere it will grow (Horn, 20052). One test will be sustained growth of scholarship into the theory and application of the discipline over decades.

Interest in service science has been growing for over a decade. Many references to a service economy can be found in marketing and operation management journals throughout the 1990s. Clearly one important acknowledgment of usefulness is the development of textbooks and broad definitions of the discipline. Fitzsimons and Fitzsimons (2001) are an example of this step with their textbook "Service Management." They proposed that service science involved transactions that are: "A time-perishable, intangible experience performed for a customer acting in the role of Co-Producer?" A great deal of impetus has been derived from IBM as a global company promoting service science as a strategic tool according to Frolovicheva (2006), a Russian IBM executive. Another significant sign of acceptance is inclusion by influential business journals like the Harvard Business Review. Chesbrough (2005) drew attention to the new discipline in the Harvard Business Review by indicating it was close to having the critical mass needed for wide spread acceptance as a business discipline. 
One can never be sure if practice causes academic research or if scholarly inquiry causes new theory to develop. Either way the surge in academic interest indicates that both scholars and practioners are finding insight into business problems through this discipline. The establishment of the Journal of Service Sciences is only possible because the number of scholars working in the field is significant. In 2007 the Journal of Production and Operations Management devoted a special edition to the subject. There are already many schools offering elective courses in this subject. For these courses to become more than electives, the courses will have to become integrated into business school curriculums. That happens when the subject is considered in the courses of other disciplines. An example of this is the mutual recognition of cost accounting and production management.

Introductory courses in accounting are unpopular and universally imposed on students seeking a respectable undergraduate degree in business. These courses are necessary because students must understand the stewardship and valuation roles of accounting, regardless of their major. This situation has evolved because accountants are deeply involved in the creation of information that managers of all types use for making decisions. A manager's ability to lead is impaired when there is a failure to understand the assumptions built into financial information. When accounting gets out of step with the informational needs of the business community our entire economy is harmed. Johnson and Kaplan (1987) triggered a revolution in accounting curriculum and practice when they declared the discipline had lost relevance. Adherence to technologies designed for railways and large assembly plants was hurting economic development. The danger of losing relevance is always present for every profession.

Service science will influence what is relevant strategy for leading firms. Another way to approach this point is to look at the ways accounting practice can impede the adoption of service science in industry. Proponents of the new discipline can avert organizational drag from outdated accounting treatment by giving due consideration to cross disciplinary research. Included in this is consideration of the accounting changes needed so that business reports fully embrace the new service paradigm. Katzan (2008) is a powerful example of this type of development. His work shows how service science methodology can link to the accounting process. Without clear, event definition, accountants will not know how to codify sales data. Without adequate coding of data it will be hard for managers to get information which is consistent with a service science paradigm. Without support there will be a systemic push-back to traditional models which are supported by accounting software. Accountants are not going to change themselves - research will have to relate service science to the stewardship and valuation propositions of the accounting discipline.

Some changes to accounting structures could be necessary for the full application of service science to be integrated into organizational life. In recent years we can appreciate this by looking at the absence of accounting reports that address carbon credits and emissions (Kerr, 2008). In the absence of real environmental cost and liability data in financial statements the issue is discounted by financial markets. It will be very difficult for service science to achieve its fullest possible traction if other disciplines do not embrace it. A regard for accounting theory will then help service science scholars point to more potential benefits of their field of study. It will also cause accounting scholars and CFOs concerned with day to day operations to focus on the subject by making it accessible in the midst of the many other priorities they face. This paper will then endeavor to offer a review of accounting thought for purposes of identifying areas of opportunity and concern for service science scholarship.

\section{AN ACCOUNTING FRAMEWORK}

Accounting reports and departments play a central role in determining what matters. Until it is measured and reported in financial statements the unrealized financial reality of a situation rarely receives much attention. Just consider the current sub-prime crisis. The liquidity imbalance and related issues were being reported in technical industry papers in early 2005 . However, it did not receive widespread attention or impact the stock market until late in 2007. That attention came when HBSC became the first financial institution to report a large loss due to portfolio write-downs. Suddenly that which was known became economically real. The stock market had to catch up with losses that it had been able to ignore for 2 years. Accounting interaction is therefore important to the future of service science because there is a real risk that many of the value propositions of the new discipline will be ignored in accounting reports. Consideration of the accounting treatments may then increase the success potential for service science applications. 
The language of accounting is driven by a conceptual framework. The overriding characteristic of that framework in decision usefulness and the authoritative explanation of this is the $2^{\text {nd }}$ Statement of Financial Accounting Concepts which was issued by the Federal Accounting Standards Board (1980). Decision usefulness is operationalized by considering the relevance and reliability of information. Each of these terms is defined further by their specific components which are also understood in specific situational contexts. These terms are quite often misunderstood because the common, rather that the professional, definition of these terms is used by nonaccountants. The resulting misunderstanding causes frustration and conflict.

An appealing aspect of service science is its fresh methodology for identifying ways a firm creates values through relationships with those it serves. That meaning of decision usefulness is not the same as the accountant's use of the same words. For an accountant the primary way of evaluating usefulness is to determine usefulness through a lens of reliability. This means that information that can be verified to objective documents is useful. Such an approach is emphasizing stewardship of shareholder investments. Unfortunately it makes recording contributions from the service science very difficult in the short run. Service science approaches will create substantial unrealized holding gains and investments in service improvements that will be expensed, rather than recognized as new assets. Such accounting treatment leads to lower net income in the short-run.

I stress this to emphasize that accounting may be a more established discipline than service science but it too is a developing and evolving discipline. Agency theory has been a very useful tool for accounting scholars. The agency impact on accounting policy can be best understood if one takes an economic perspective (Christensen and Feltham, 2003). The economics of information does determine what has gone into the structure of accounting reports. Accounting reports depend on the receipt of good information and organizational context. Accounting reports depend on information received from participants. Accountants impact the form of the report. The setting of the report and impact of the report on public and private information is critical. Service science will have to relate to accounting systems if it is to be considered in the practice of accounting.

Service science is in a stage of fresh exuberance. One must not forget that all other business disciplines may be more established but they are also growing and still competing for their place. Mattessich (2006) noted that the agency relationship is constantly exerting pressure on accounting to become purpose driven. As one of the leading researchers in the discipline his observation is important. Mattessich was pointing out that accounting responds to changes in our economic environment and that what counts does change over time.. Service science can exert a new pressure on the discipline to change how investments in value creating personnel and technology are counted.

A stated reason the emergence of service science is its ability to give new insight into value creation as a broader partnership between supplier and customer. Accounting has an interest in recording valuation adjustments. However, motivation to record expenditures as assets that create lasting value is in conflict with the motivation behind recording management's stewardship of the stockholders capital. Accountants face a moral hazard in this conflict that other disciplines do not face. Accounting produces information for the stockholders and this creates a complicated agency relationship. Objective evidence is hard to obtain for most expenditures that are directed at creating long term value which causes a bias against recognizing assets in financial reports. Liang (2006) is one of the many leading accounting researchers grappling with this problem. Voluntary disclosures of the value proposition by managers reduce cost of monitoring and evaluating needed by accounting professionals. This also builds trust. Moral hazard results because accountants bear more of the cost and risk associated with valuation errors than other managers. However, the resulting undisclosed holding gains can undervalue management performance. The bias will impede recognition of contributions from the application of service science in financial reports.

Service science scholarship must develop basic theory and framework for the field. Cross disciplinary respect and cooperation will strengthen the relevance of that developmental work. Work by scholars like Bryson, Daniels, and Warf (2005) are important because they provide a quality of conceptualization about service science that I find enlightening. It gives structure that allows for a meaningful comparison of how areas of study will impact each other. Conceptual theories provide structure through which we understand existing disciplines. The service science focus on the configuration of technology, specialization, and processes creates new perspectives. What has 
yet to develop is a deep understanding of the relationship with accounting. Accounting is the language of business but it also provides a deep social structure that controls how resources as viewed and allocated. Service science is proposing deep changes in organizational thinking.

Another way to view this is through the argument of Spohrer and Maglio (2008). IBM was ground zero for the discipline and they were working within IBM to build up the methodology. They mention the need to get service science included in marketing, operations, and management curriculums but never mention accounting. However the application of service science encourages firms to invest in technology, talent, and work environment enhancements. An accountant may see these expenditures as good business practice but will not record them as assets. Accounting will treat the last 2 as overhead cost increases. Technology will also be written off to the income statement on an accelerated basis. The gains in "goodwill" will never show up on a balance sheet until net income increases. Even then the gain will show up as cash and retained earning-not as goodwill and other long term assets. So the service science motivated investments will result in lower income ratios and profits than competing firms during implementation years. Unless expenditure into the service science paradigm can be treated as investments by the accounting system, service science scholars will experience the need to create their own monitoring and valuation systems.

The creation of separate valuation systems is certainly more attractive than fighting for favorable financial treatment. Many historic examples of this can be considered. Consider how quality management ideas developed in each business discipline. For example, one way accounting embraced quality management was through the development of activity based costing. At the same time supply chain management embraced development of ISO protocols. The underlying processes behind ISO and $\mathrm{ABC}$ implementation are the same. The difference is which functional silo was in charge. Larson and Kerr (2007) found convincing evidence that companies that adopted both approaches decreased profits over those that adopted one. One approach caused creativity but a second set of analysis caused managers to focus on complying with reporting demands. It was easier for production to build their own set of reports than engage accounting to change the reporting processes. The new field will have a better life expectancy if it engages in the service research with other disciplines. While harder in the short-run the achievement of favorable treatment will create a more lasting economic contribution.

The accounting discipline creates value by guarding the resources of the organization and providing useful information that is valued because it is independent. Service science will require special attention in terms of several areas of accounting practice. The following section explores areas where accounting practice may be a concern to service science adopters. Each area offers an opportunity for fresh scholarship. No doubt the proponents will find success much easier if they understand how their methodology will be affect financial reports. Better yet would be discussion about what is needed to change those reports to reflect the insights service science has to offer. Such enlightenment will foster success and reflect the agency relationship between managers, accountants, and stockholders.

Service science practioners can learn from the experiences of just in time (JIT) inventory methodologies. Accountants do not expense fixed production costs when they are incurred. These costs flow through inventory. During implementation JIT will cause net income to decline as both current and past expenditures are expensed. As a result a great many applications of JIT were a flop due to the financial treatment. Accounting measurements reflected a different paradigm than the long-term perspective of JIT proponents. In combination with the inability of managers to relinquish control to achieve cooperation in the supply chain, adoption of JIT made things much worse for adopting firms (Bowman, 1995). The existing ideas of service science risk similar dangers without interdisciplinary consideration. If the deep social structures of accounting practice are not addressed the application of service science could be impaired or doomed. The purpose of the next section of the paper is therefore to explore areas of potential conflict and thereby create opportunities to advance both disciplines.

\section{ACCOUNTING FOR SERVICE SCIENCE}

The accounting profession creates value in 3 ways. The most evident way it creates value is through financial reports. The internal and external procedures required for these reports add credibility to management assertions. The second way accounting creates value is by turning financial data into information that managers rely 
upon to make decisions. Accountants create value in a third way by identification and valuation of assets which they then track to protect stockholder collateral. These roles manifest themselves in many routine ways. However routine those accounting systems and procedures may seem that are costly. The investment for design and implementation of new systems is hard to obtain from general management and so there is a great deal of resistance whenever change is proposed. Some of the established systems and procedures of the accounting discipline may not be favorable towards the implementation of a service science perspective. Still, accounting research does consider the special circumstances of service organizations. However a service science scholar will have to address some problems in parallel with the accounting research to overcome systematic barriers to implementation of their ideas.

In order to identify potential areas of unfavorable treatment a basic review was conducted. Two well respected and current management accounting textbooks were selected. These books were reviewed for references to service environments or areas of investment emphasized in the service science literature that was reviewed earlier in this paper (Eldenburg \& Wolcott, 2005)(Garrison, Noreen, \& Brewer, 2008). Five areas of accounting practice appear to present an obstacle to those wanting to succeed by strategically embracing service science based on this rudimentary review. The following sub-sections offer a prospective explanation of areas that merit deeper cross disciplinary examination.

\section{Capital Budgeting}

Budgeting cycles of all organizations follow a predictable pattern. Through strategic and other negotiations a sales budget is established. The sales budget becomes the key determinant for production and administrative budgets. This establishes the income statement expectations for the year. The related operating budgets then provide the basis of balance sheet considerations. That consideration includes investments in long lasting assets and changes to the capital structure of the organization. Capital budgeting has a long-term focus and comes with a set of procedures that are worth considering in the context of service science.

Service science calls for investment into intangible items that help the provider and their customer coproduce value. A firm embracing this model will tend to make more investments in personnel and work processes than a traditional, production oriented firm. Intangible investments like this will not go onto the balance sheet. Investments must meet strict rules of capacity creation and objective valuation before an accountant can include them on the balance sheet. This means that managers implementing a service science approach will initially have to seek larger operating budgets than their counterparts using a more traditional approach because many of these "investments" will not be recorded as capital items. Over a number of quarters or years it will take for the investment approach to yield higher pricing, volumes, or both the quarterly income of the firm will be depressed by this accounting approach.

Some aspects of the service science model stress the importance of the service environment and service technology. These items will usually go onto the balance sheet because their value is objectively determined and use over future periods is ascertainable. The financial perspective on such assets, influenced heavily by tax considerations, is that these items depreciate rapidly. Proposals for these investments must compete with all capital investment proposals for the limited resources of the firm. Faced with relatively higher depreciation rates in the early years such investments face a higher hurdle for funding. An advocate of a service science approach will have to be more skilled that an traditional manager in constructing the numbers to even up the field.

The capital budgeting challenge is exasperated by an additional challenge- the status quo. Returns from capital investments are normally determined in comparison to the existing methods of doing business. Such an approach will work against the service science advocate. It is clear that once one firm invests to increase their value creation potential that status quo for others in the same market has changed. Capital budget proposals often neglect this consideration and thereby contribute to tendency of firms with highly developed accounting systems to resist new paradigms until others have changed the status quo. Advocates of service science methodologies will have to consider closely how to overcome the systemic capital budgeting bias against the classes of assets their discipline is featuring. Service science research can collaborate with accounting to explore ways to gain "useful" valuations. 


\section{Responsibility Accounting}

Responsibility accounting is a label using in accounting literature to group together decisions about how to subdivide a firm into work units. At the heart of this concept is agency theory. At the introductory level, the generic types of responsibility are: cost centers, revenue centers, profit centers, and investment centers. The selection process is meant to align reporting details with the responsibilities of managers. An ideal situation arises when accounting reports for managers only include those items over which a manager has authority. In this way responsibility accounting promotes accountability and facilitates good governance for each and every internal agency relationship the organizational structure has created.

Implementation of the simple, yet radical approach of service science will require realignment of the types of responsibility accounting divisions that currently exist. Division into units represents a large administrative investment. The procedures and policies required to organize information into existing units are deeply imbedded into organizational life and information systems. They also become a form of psychic contract between all the players. Implementation of service science as it is understood today will necessitate more than a change in managerial attitudes. It will require firms to continuously reorganize to co-create value as conditions change. Consider the organization of a law firm to illustrate this problem. A typical firm can be organized into practice departments such as civil litigation, taxation, and family law. A leadership structure will exist for each area. Accounting procedures and reports are designed to create stability around those divisions. A new view of creating value for a client will require reorganization of those procedures and reports to give it validity. Without such a change the accounting mechanism will draw attention away from the service science approach.

A related problem is that accounting practices will not record or capture data about some of the most significant contributions of service science. Consider the exploration of Hay and Hill (1999) into service failures. The key analytical information is missing in accounting systems. An accounting system does not reveal the costs of customer dissatisfaction from a service science perspective. A cut in cost by reducing service personnel is immediately reported as a cost saving. The sale that is lost because a potential client could not wait is never recorded. This establishes a bias regarding what is good in responsibility accounting cycle. Some slack resources might be exactly what are needed to ensure the provider of service and the customer can jointly respond to opportunities to create new mutual value. Traditional approaches to effectiveness will not support this paradigm in quarterly financial reports. It will be a challenge to create responsibility accounting structures that reset the psychic contract in ways that affirm the service science approach.

\section{Service Costing}

Cost information is a crucial input when special and regular pricing decisions are being made. The process involves many arbitrary and potentially capricious cost allocations by accountants. Accountants develop procedures, such as time sheets, to accumulate direct costs of a customer. Indirect costs such a technology support, training, and research capacities can be critical to providing service but extremely difficult to attribute to a specific situation. When Katzan (2008) shows how the service science approach will change the classification of services the value is easily understood. Traditional and newer models of cost allocation can address these information needs. However the sticky nature of systems and procedures has to be kept in mind to guard against assuming reports will easily or automatically change in support of the new paradigm.

Accountants have a long tradition of struggling with how to provide cost information about services. In the context of losing relevance, Dearden (1978) stressed the impact of cost accounting on service industries in the Harvard Business Review. Since that time almost all advance management accounting books have devoted separate chapters to the costing issues associated with a service organization. Service science expands the definition and scope of firms that should be considered in this classification. Accountants can use normal costing in a manufacturing situation to handle short term fluctuations in unitization. An equivalent for service firms has been illusive due to the lack of inventories. As a result, the costs of service tend to fluctuate more than costs of manufacturing. These costing vicissitudes are not consistent with the idea of co-producing value with a client. 
Addressing this difficulty could lead to a costing error by service science practioners. It will be easier to create alternative cost analysis within the units delivering a service or in direct relationship with clients. Anecdotal research found that same dynamic when quality departments independently pursued ISO registration (Larson and Kerr, 2002). The work started by Katzan needs to be extended to relate to the necessary costing support as an example of a way to overcome the obstacle of information in forms that do not support new ideas about how value is created. Until this research happens, advocates of service science could inadvertently increase their costs through duplication of information systems. Of course, the improvement in value creation might be so great that the cost duplication can be considered a necessary investment.

\section{Cost Volume Profit Analysis}

Cost Volume Profit (CVP) analysis is a managerial tool used to evaluate a firm's cost structure, break-even point, and operating leverage. It is also used by most senior managers to make quick assessments of proposed changes to the firms cost structure. The service science model advocates investment into talented personnel and performance offerings (Spohrer and Maglio, 2008). This emphasis will create changes in a firms cost structure. To the extent these changes increase financial vulnerabilities the service science model will experience resistance from those that rely on this basic accounting tool.

Established service firms have a higher reliance on fixed costs. A successful firm will secure highly talented staff though the stability of full time employment contracts. It will also favor the security of supply that comes from owning key technology. As a result, a service firm that is fully pursuing new approaches to joint value creation will also likely increase its fixed costs. The impact of this in a accounting sense is that the firm becomes more vulnerable to shifts in sales. Incremental revenue causes little increase in the cost of these firms. This kind of business structure would increase the needed break-even volume but also significantly increase in operating leverage. When performing at, or near break-even, such a firm will be far more vulnerable to splashy losses than those with more variable costs due to their relatively lower staffing commitment and or investment in technology.

The emphasis on contribution margin might lead to bidding errors. Much of the rotating bankruptcy situation in the US airline industry can be attributed to this. Until recently their major costs were capital commitments to aircraft and airport facilities. It was very easy to bid down the price to fill seat capacity to maximize the short run contribution margin. The variable costs for this service are a small portion of the total economic cost. Over time though the infrastructure has to be paid for regardless of how positive income from operations is. The proponents of service science will need to consider this financial metric. Accounting departments have a natural propensity towards variable costs because it reduces financial risk. Decreased profits from diminished margins at higher volumes are less of a problem than negative cash flow in an accounting paradigm. Plans to move towards more fixed costs will run into a headwind from accounting. The value proposition will have to be more comprehensively documented than an equivalent cost reduction proposal to invest in cost cutting. Another possible solution is to tie into an emphasis the accounting literature that views utilization as a way to increase valuation.

\section{Capacity Utilization}

Capacity unitization is emphasized by accounting and operations management scholars with regards to their definition of service management. A simple illustration reveals why. A hair stylist rents a facility for $\$ 1,000$ per day in the business district to be convenient for his clientele of CEOs. Movements from 1 to 2, 8 to 9, or any other practical increase in utilization make a powerful change in the cost per customer. This dynamic is why service pricing is so problematic (Brignall, 1991). Price competitive providers are those that allocate customers to fit into their limited service capacity. A common example would be an accounting firm pushing eligible clients to adopt a June $30^{\text {th }}$ year end to make use of idle staff in the summer. It is a capacity driven approach.

Service science elevates the capacity consideration with its new value proposition. Rather than pushing on a price-volume continuum it provides a tool for negotiating value in additional ways. The stylist might achieve higher rewards and his clients' greater value from a negotiation of service terms. Through this process both may achieve a more meaningful long run mechanism for creating lasting value. This is a more meaningful response to 
surplus capacity than increasing sales which could in fact hurt the value of the provider to busy CEOs. Accounting research is also pointing in this direction as evidence in Brignall's (1996) deepening of the link between utilization strategies and performance measurement. Synchronized vocabulary could release awesome collaboration.

The greatest problem to resolve is the approach to issues arising when capacity of a scare resource is reached. An accounting approach is to pull out the theory of constraints. Management is encouraged to promote the services that make the most contribution per containing factor-for example the stylist's facility. In the longer term, investment is directed towards the constrained factor until a new constraint becomes binding on the firms ability to serve clients. This approach encourages accounting and operations professionals to push those in contact with clients towards a prescribed mix of services and products to offer. It is a classic power struggle that occurs whenever capacity limits are reached. Adoption of a service science approach will increase this struggle. The concept of co-producing value will have to be integrated with the prevailing theory of constraints if practioners wish to have lasting success. Settling service rules to reduce capacity conflicts is an easier administrative solution than negotiation of a relationship with clients as envisioned by a service science approach.

\section{FINANCIAL REPORTING}

Research into the 5 areas of concern will help the discipline of service science decrease organizational resistance to their ideas. There is a great number of accounting scholars that would argue that contribution of other disciplines are irrelevant to the stewardship responsibility of accounting the accounting discipline. According to this view, regardless of the sector or strategies employed, investors want to receive information about their investments in the familiar format of financial statements. The stewardship mandates leads to highly reliable information in the narrow accounting definition of reliable. This reliability creates an unavoidable temptation to extend accountability into performance evaluation. Scholars have thoroughly explored and explained the problems with this approach and have been largely ignored. I do not foresee anything about service science that will allow it to escape this situation either.

Valuation issues tend to fall into the realm of management accounting. Most of the comments in the previous section are managerial topics. Management accounting has created some powerful performance evaluation tools that do reflect the valuation aspect of information usefulness. Standard costing, economic value added (EVA), and the Balanced Scorecard are all techniques aimed at creating a measurement balance. I do think that service science will achieve greater acceptance if research in the field contributes to these evaluation techniques that supplement financial statement information.

Oliva and Sterman (2001) were on a useful track when they created a 2 by 2 taxonomy for classifying service firms. They classified service firms by considering whether they use human systems or mechanical systems. On the other axis they classified service firms by the extent to which they help their clients - do some if it or do all of it. This provides a useful way to view how the parties create value for each other. For example a firm offering to meet all of a client needs for a service through human systems is delegating work through outsourcing. They distinguish this from a similar situation were the service is all provided by a tool system - an automated, self service solution. This is useful because the types of measures needed to achieve accountability are obviously different. So while service firms cannot expect financial accounting statements to reflect the valuation advantages service science is offering they can address the issue through insightful contributions to the performance evaluation methods deployed in managerial accounting reports.

Service science can gain increased rates of recognition by connecting with management accounting practices outlined here. The value creation proposition of service science presents opportunities for better models of capital budgeting. Economic value added analysis could achieve more relevance through a broader idea of service assets the new discipline appears to be generating. Deeper insight into the process of service innovation is also valuable. The strategic purpose of the balanced scorecard will be enhanced when better leading indicators for service innovation arise. These sorts of connections will tie the new discipline into existing curriculum. If service science can enhance the practice of accounting it will earn an important source of credibility while also removing a barrier to its own success. 


\section{CONCLUSIONS}

This paper set out to explore how the emerging discipline of service science will relate to the scholarly and professional practice of accounting. This preliminary overview has revealed that service science could improve the state of accounting research into the service sector. Financial accounting practices are not able to capture the value creation attributes of a service science approach. Scholars in the area of service science need to be cognizant of the deep social structures that are imbedded in accounting practice. If the new discipline can help scholars build trustworthy mechanisms for valuing service assets these developments will be valuable to accounting scholars and create significant intellectual capital. While it is necessary for the new discipline to focus on its own conceptual development it can avoid the errors of fanciful theoretical concepts that may develop if research is limited to intradisciplinary questions. Concurrent development of connections to related accounting research will keep the process on a mutually beneficial useful track. The editors of this new journal are to be complimented on establishing a journal dedicated to the new discipline with just such a cross disciplinary awareness.

\section{CITATIONS}

1. $\quad$ Bowman, Robert (1996). Has JIT flopped? Distribution. Rador: June 1996 Volume 95, Issue 7, Page 28.

2. Brignall TJ, Ballantine J (1996). Performance Measurement In Service Businesses Revisited. International Journal of Service Industry Management. Vol 7 no 1 pp 6-31

3. Brignall TJ, Fitzgerald L, Johnson R, Silvestro R, (1991). Product Costing In Service Organzations. Management Accounting Research. Volume 2 pp 227-48

4. Bryson JR, Daniels PW, and Warf B (2004). Service Worlds: People, Technology, Organizations,. Routledge. London

5. Chesbrough, H. (2005). Towards A Science Of Services, in Breakthrough ideas for 2005. Harvard Business Review. Volume 83, Issue 2, 43-44

6. Christensen PO, and Feltham GA, (2003). Economics of Accounting, Volume 1: Information Markets. Boston: Kluwer Academic Publishers.

7. Christensen PO, and Feltham GA, (2005). Economics of Accounting, Volume II: Performance Evaluation. Boston: Kluwer Academic Publishers

8. Eldenburg Leslie, and Wolcott Susan, (2005). Cost Management: Measuring, Monitoring, and Motivating Performance. John Wiley: USA

9. $\quad$ FASB (1980) Statements of Financial Accounting Concepts 2: Qualitative Characteristics Of Accounting Information, The Federal Accounting Standards Board, New York.

10. Fitzsimmons, James Fitzsimmons, Mona (2001). Service Management: Operations, Strategy, and Information Technology $3^{\text {rd }}$ edition. McGraw-Hill: New York

11. Frolovicheva Katerina (2006). The Emergence of Service Science: Towards Systematic Service Innovations to Accelerate the Co-Production of Value. Journal of Global Business and Technology. Huntington Station: Fall 2006 Vol. 2, Iss. 2; pg. 39, 17 pgs

12. Garrison Ray, Noreen Eric, Brewer, Peter (2008). Managerial Accounting-12 $2^{\text {th }}$ edition. New York: McGraw Hill.

13. Hay JM, Hill AV (1999). The Market Share Impact Of Service Failures. Production and Operations Management. V8N3 Fall 99 208-220

14. Horn, Paul (2005-1). The New Discipline Of Service Science. BusinessWeek. January $21^{\text {st }} 2005$

15. Horn, Paul (2005-2). Building a Science of Services. Business Week. June $21^{\text {st }}, 2005$

16. Johnson, H.T., Kaplan, R.S. (1987). Relevance Lost: The Rise and Fall of Management Accounting, Harvard Business School Press, Cambridge, MA.

17. Katzan, H, (2008). Event Differentiation in Service Science, Journal of Business and Economic Research Volumes 6 Number 5, pp141-152

18. Kerr, Stephen (2008) Getting Ready For A Carbon Credit Market. Journal of Applied Business Research, Fall 2008.

19. Laing, Pierre Jinghong (2000). Accounting Recognition, Moral Hazard, and Communication. Contemporary Accounting Research. Vol 17 No 3 (Fall 2000) pp457-90

20. Larson, Paul and Kerr, Stephen (2002). ISO and ABC: Compliments or Competitors? International Journal of Logistics Management. 2002, Vol. 13 Issue 2, p91-100, 
21. Larson, Paul and Kerr, Stephen (2007). Integration of Process Management Tools to Support TQM Implementation: ISO 9000 and Activity-Based Costing. Total Quality Management \& Business Excellence. Jan-Mar2007, Vol. 18 Issue 1/2, p201-207

22. Mattessich Richard (2006). The information Economic Perspective of Accounting: Its Coming of Age. Canadian Accounting Perspectives, Volume 5 No. 22006 Pages 209-26

23. Olivia, R, Sterman JD (2001) Cutting corners and working overtime: quality erosion in the service industry. Management Science. 47 (7) 894-914

24. Schroeder, R.G., (2008). Production and Operations Management, Introduction to the Special Issue on Theory Development in Operations Management. May/Jun2008, Vol. 17 Issue 3, p354-356, 3p

25. Spohrer, Jim, Maglio P. (2008) Production and Operations Management: The Emergence of Service Science: Toward Systematic Service Innovations to Accelerate Co-Creation of Value. May/Jun2008, Vol. 17 Issue 3, p238-246, 9p

\section{NOTES}

